\title{
Výukové cíle v primárním vzdělávání aneb Cesta tam a zase zpátky
}

\author{
Jana Stará, Karel Starý
}

\begin{abstract}
Abstrakt: Cúl: Popsat, jak o výukových cílech v sociálně-humanitnim vzdèláváni uvažuji učitelé 1. stupně ZŠ, jaké cíle si ve výuce stanovuji, jak je zprostředkovávají žákưm a jak s nimi ve výuce pracuji. Metody: Viceprípadová exploračni studie, prípadem je práce učitele se vzdèlávacími cíli. Úćastnicemi výzkumu bylo 10 učitelek 1. stupně ZŠ. Jako metody byly použity pozorováni ve výuce, hloubkové polostrukturované individuálni rozhovory s učitelkami a obsahová analyza výukových artefaktü. Výsledky: Vzdělávaci cíle se ve výuce nevyskytuji v explicitni formè. Pŕi pozorováni se implicitni cile vynořovaly - na začátku hodin prí sdèlováni programu, $v$ prüběhu hodin při řešeni učebnich úloh a predevšim při hodnoticich procesech věetně závèrečné reflexe. Nejzřetelnèji se vzdèlávaci cíle ozrejmovaly při použiváni kriteriálního hodnoceni. Kvalita a zpuisoby práce s cili u zkoumaných učitelek byla velmi rüznorodá. V mnohých hodinách byly $v$ nesouladu vzdèlávaci cíle, výukové metody a hodnoceni žákì. V rozhovorech učitelky explicitnè neuvádély rozvoj hodnot jako to, o co ve výuce usiluji. Závèry: Pokud jsou cíle, obsah a hodnoticí postupy v souladu, prináši to pozitivni duisledky pro učeni žákü. Analýzou výrokù učitele a jejich odezvy u žákủ jsme dospèli k názoru, že zdokonalení práce s výukovými cíli má potenciál prinášet žákưm vètši zisky z učeni a celkově zkvalitňovat jejich vzdèláváni. Vzhledem k velkým rozdílìm mezi učiteli nám pripadá důležité individualizovat jejich podporu.
\end{abstract}

Klíčová slova: výukový cíl, vzdělávaci cíl, primárni vzdèláváni, realizované kurikulum, prípadová studie, sociálnè-humanitni vzdělávání.

\section{ÚvoD}

Za jeden z klíčových předpokladů kvalitního učení je obecně považováno žákovo pochopení toho, čemu se má naučit, kam výukové aktivity směřují, jak pozná, že kon- krétní znalosti a dovednosti ovládá. Za tímto účelem byly vyvinuty konkrétní výukové strategie jako např. organizátory postupu (advanced organizers), ${ }^{2}$ které žákům pomáhají propojovat nové informace $s$ dosavadními znalostmi a podporovat tvorbu jejich vlast-

\footnotetext{
${ }^{1}$ Tento článek byl podpořen projektem GA ČR 15-19158S: Formativní hodnocení žáků prostrédnictvím vzdělávacích cilu.

${ }^{2}$ Pojem advanced organizers je spojován především s americkým psychologem D. P. Ausubelem, který jej používal od šedesátých let 20 . století.
} 
ních kognitivních struktur (Joyce \& Weil, 1972). Další strategie jako průběžné dělání poznámek (note taking) či závěrečné sumarizování pak podporují nejen porozumění vzdělávacímu obsahu, ale také jeho účinnou fixaci v dlouhodobé paměti žáků (Walberg, 1999; Marzano, Gaddy \& Dean, 2000; Hattie, 2009; Starý, 2006). Koncept výukových cílů umožňuje volbu a uživání efektivních výukových strategií pro žákovo učení.

Zajímali jsme se o to, jak čeští učitelé stanovují vzdělávací cíle a jak s nimi ve výuce pracují. Domníváme se, že realita českého školství nebyla zatím v této oblasti dostatečně empiricky prozkoumána a že by takto zaměřený výzkum mohl přinést poznatky užitečné pro př́pravné i další vzdělávání učitelů. Koncept vzdělávacích cílů je intenzivně a dlouhodobě rozvíjen $\mathrm{v}$ americké pedagogické psychologii (goal, aim, objective). Podrobnější popis překračuje možnosti této studie, a tak jen upozorníme, že do české pedagogické terminologie se dostal především díky P. Byčkovskému a J. Kotáskovi. Velký význam má především jejich společný článek (Byčkovský \& Kotásek, 2004), kde autoři mimo jiné navrhují české ekvivalenty pro anglické pojmy. Některé z nich se již ustálily, jiné nikoli. Klíčovým obecným pojmem je vzdělávacíi cíl (educational objective), který je zastřešujícím pojmem pro další členění cílů. Vzdělávací cíle se vyskytují na různých úrovních vzdè- lávacího systému v oblasti vzdělávací politiky, v kurikulárních dokumentech apod. Jakmile se vzdělávací cíle přímo dotýkají vyučování a učení, mluvíme v souladu s Marešem (2013) o výukových cílech. Mareš (tamtéž) také správně upozorňuje, že výukové cíle se týkají kromě kognitivní oblasti i cílů afektivních a psychomotorických. Také v sociálně-humanitní oblasti, které se týká naše studie, vystupují do popředí cíle afektivní.

Hlavní výzkumnou metodou našeho výzkumu bylo pozorování, protože - jak uvádějí Slavík et al. (2017, s. 312) - „... nestačí jen znát kvalitu znalostí nebo názory žáků, dokonce ani názory učitelů, protože je zapotřebí vědět, jak kvalitně ve trrídách učitelé vyučují a žáci se učí. Věríme, že náš výzkum založený na pozorování hodin, i když není př́liš̌ rozsáhlý, umožní lépe porozumět tomu, jak mohou výukové cíle pomáhat žákům při učení v podmínkách běžných českých škol.

$V$ tomto článku se zaměrujeme na učitele 1. stupně ZŠ a jejich výuku neprírodovědné složky prvouky, vlastivědy a literární výchovy. Motivací pro toto zaměření nám byla (kromě naší specializace) také specifika této oblasti vzdělávání. Některé kurikulární oblasti totiž mají jasnou vnitřně hierarchizovanou strukturu, napřr. výuka matematiky nebo cizího jazyka, kdežto ve společenskovědním nebo lépe sociálně-humanitním učivu ${ }^{4}$ se jedná spíše o široké horizontální uspořádání, z něhož

\footnotetext{
${ }_{3}^{3}$ Problém spočivá i v tom, že pojmy education, educational mají jiný obsah a rozsah než pojmy vzdělávání, vzdělávací. Jestliže $\mathrm{v}$ angličtině je pod education svým způsobem podřazena i výchova, $\mathrm{v}$ češtině zpravidla mluvíme o výchově a vzdělávání jako o samostatných entitách (nap̌r. Mareš, 2013, s. 295).

${ }^{4}$ Termín sociálně-humanitní prédmèty navrhuje Beneš (2009) jako vhodnější než společenskovědní s odkazem na dualitu individuálního a sociálního rozměru lidského bytí. $S$ termínem se lze již setkat v některých publikovaných studiích (např. Stará \& Starý, 2017). Podobně se ve vzdělávání používá termín osobnostně-sociální výchova.
} 
se pro školní vzdělávání vybírají jednotlivé víceméně nezávislé tematické celky - vazby mezi nimi nejsou zdaleka tak zřejmé a jednoznačné jako ve výše uvedených předmětech. Dále vstupuje do hry relativně silně ukotvená kulturní zakotvenost sociálně- humanitního vzdělávání a vnímání značné kurikulární svobody českých učitelů primárních škol (Stará \& Krčmáŕová, 2014).

Volba vzdělávacích cílů a práce s nimi je tedy v sociálně-humanitním učivu důležitá, protože do značné míry určuje, jaké základy žáci získají v pohledu na člověka a lidskou společnost. Domníváme se, že při volbě a realizaci vhodných sociálně-humanitních cílů potřebují učitelé podporu naléhavěji než $\mathrm{v}$ ostatních součástech kurikula, protože do značné míry vybírají a zprostředkovávají žákům to, co je podle jejich subjektivního přesvědčení důležité. Již $\mathrm{v}$ předchozích výzkumech jsme zaznamenali značnou variabilitu př́stupů učitelů $\mathrm{k}$ výuce např. prvouky či vlastivědy (Stará \& Krčmářová, 2014; Stará \& Starý, 2017).

\section{TEORETICKÁ VÝCHOdISKA}

Cílem stanovování cílů ve výuce je dát procesu učení žáků jasněǰš́ strukturu. Jestliže mají výukové cíle dobře posloužit žákům a plnit roli, která se od nich očekává, musí jim žáci rozumět a identifikovat se s nimi. Neměly by proto být př́liš úzce vymezené, pak totiž hrozí riziko př́lišného soustředění na výukový cíl, v extrémním př́padě až po negativní „učení se na testy" (Marzano, Pickering \& Pollock, 2001). Opačným extrémem jsou cíle pří- liš obecné. Přiměřená obecnost formulace výukového cíle je důležitá $\mathrm{i} z$ toho důvodu, aby v nich měli žáci dostatečný prostor pro personalizaci, tj. přizpůsobení cílů svým potřebám a zájmům (Bandura \& Schunk, 1981; Novotná \& Krabsová, 2013; Laufková, 2016). Velkým rizikem je i jednostranné soustředění cílů na kognitivní poznatky a opomíjení afektivních a psychomotorických cílů, jejichž význam především v dlouhodobém horizontu nabývá na důležitosti.

Se stanovováním výukových cílů esenciálně souvisí poskytování zpětné vazby. Pokud žákům není jasné, kam směřují, jen těžko mohou pochopit informace o tom, jak se jim daří. Průběžná zpětná vazba je klíčovým prvkem formativního hodnocení (např. Laufková, 2017). Pozitivní vlivy zpětné vazby na proces učení byly jednoznačně výzkumně prokázány (Scheerens \& Bosker, 1997; Torrance \& Pryor, 2001; Chappuis, 2005; Marshall, 2011; Shepard et al., 2012). Za zpětnou vazbu nelze považovat pouhou informaci o správnosti či nesprávnosti odpovědi žáka (ústně nebo v testu). Zpětná vazba musí být „korektivní $v$ tom smyslu, že poskytne informaci, co je na žákově odpovědi správně a co nesprávně. $\mathrm{V}$ optimálním př́ípadě poskytuje žákovi účinnou nápovědu, aby sám identifikoval chybu a dospěl ke správnému řešení. Pro zpětnou vazbu je zásadní také včasnost a používání kriteriálního hodnocení místo normativního (Marzano et al., 2001). Stanovování cílů a poskytování zpětné vazby je vzájemně propojeno. Bez dobře formulovaných cílů nelze poskytovat kvalitní zpětnou vazbu, a pokud sta- 
novení výukových cílů není následováno poskytováním zpětné vazby, ztrácí explicitní vyjádření výukových cílů do značné míry smysl (Cauley \& McMillan, 2009; Chappuis \& Chappuis, 2007; Hattie \& Timperley, 2007). Zpětnou vazbu přitom nechápeme jako činnost výhradně patřící učiteli. Již Wiggins (1993) prokázal, že žáci jsou schopni účinně hodnotit své vrstevníky i vlastní pokroky v učení. K tomu jim explicitní formulace cílů mohou poskytovat dobrou oporu (Clarke, 2005; McTighe \& O’Connor, 2005; et al., 2008; Laufková, 2016).

Svým textem si dovolujeme reagovat také na výzvu Strakové a Slavíka (2013, s. 280), kteří v editorialu monotematického čísla Pedagogiky 3/2013 sdělují: „Vše nasvědčuje tomu, že čeští výzkumníci se málo zabývají studiem konkrétních podob hodnocení $\mathrm{v}$ konkrétních předmětech a nezaměřují se ani na sledování dopadů hodnocení na učební výsledky žáků."

\section{MetodologIE VÝZKUMU}

\subsection{Cíle výzkumu a výzkumné otázky}

Obecným cílem výzkumu bylo popsat, jak o vzdělávacích cílech učitelé uvažují, jaké cíle si ve výuce stanovu- jí, jak je zprostředkovávají žákům a jak se $\mathrm{k}$ nim ve výuce vracejí. Byla naformulována hlavní výzkumná otázka: Jak učitelé ve výuce na úrovni ISCED 1 $v$ sociálnè-humanitním vzdèláváni pracuji s výukovými cíli? Tato otázka byla následně rozdělena na specifické výzkumné otázky: 1. Jaké cíle si učitelé stanovují?, 2. Jak o výukových cílech uvažují?, 3. Jak je využívají při hodnocení žáků?

\subsection{Výzkumné metody}

Vzhledem $\mathrm{k}$ záměru výzkumu jsme se rozhodli volit design kvalitativního výzkumu. $Z$ a výzkumnou strategii byla zvolena př́padová studie, zejména proto, že usiluje o komplexní porozumění zkoumanému jevu $\mathrm{v}$ přirozeném prostředí (Yin, 2009). Vzhledem ke zkoumání několika př́padů lze př́padovou studii označit jako vícečetnou nebo hovořit o vícepř́ípadové studii (Dvořák et al., 2010). Podle Yinovy klasifikace se jedná o explorační ${ }^{5}$ př́padovou studii, nebot́ cílem bylo sledovaný jev nejen popsat na základě toho, jak se jeví při pozorování, ale také pomocí hloubkových rozhovorů proniknout do toho, jak jev chápou učitelé (Yin, 2009). Analýza dat tak vedla $\mathrm{k}$ hledání „předpokládaných prríčinných vztahü“" (Mareš, 2015).

\footnotetext{
${ }_{5}^{5}$ Explorační nebo exploratorní př́padovou studii chápeme jako takovou, která analyticky prozkoumává určitý jev v přirozeném prostředí. Není pouhou deskripcí, snaží se o porozumění jevu, ale nesnaží se jev komplexně vysvětlovat. Odpovídá tedy spíše na otázku JAK? než na otázku PROČ? I když jsme se zabývali otázkou po motivech jednání učitelů (rozhovory), nepodařilo se nám data natolik teoreticky saturovat, abychom se odvážili zobecňovat jejich subjektivní vysvětlení do nějaké teorie, což by studii dávalo vysvětlující (explanační) charakter (Mareš, 2015).
} 


\subsection{Př́ípady a jejich výběry}

Jednotlivými př́pady pro nás byly odlišné přístupy, jak učitelé pracují ve výuce $s$ cíli. Vycházeli jsme z teoretického předpokladu, že přístup $\mathrm{k}$ výuce je u učitelů poměrně stabilní (nap̌r. Fenstermacher $\&$ Soltis, 2008). Ustálený prŕístup učitele se liší více mezi různými vyučovacími předměty než mezi vyučovacími hodinami jednoho předmětu (Stodolsky, 1988). Proto pro nás bylo důležité, že se jednalo o výuku v sociálně-humanitních předmětech $\mathrm{v}$ prvouce, vlastivědě a literární výchově.

$Z$ 1. stupně ZŠ byly osloveny nejdřive tři ředitelky fakultních škol, s nimiž členka výzkumného týmu spolupracuje $\mathrm{v}$ oblasti pedagogické praxe pregraduálních studentů. Na základě konzultace členky výzkumného týmu a každé z ředitelek byly předvybrány učitelky, které vyhovovaly potřebě sestavit dostatečně pestrou skladbu účastníků výzkumu. Tyto učitelky spolupráci přijaly. Oslovené školy byly vybrány $\mathrm{z}$ důvodu, že na ně měli členové výzkumného týmu kontakty, byly pro ně relativně snadno dostupné a dohromady tvořily různorodé složení. Jedna je školou sídlištní (Společná), druhá školou v pražské rezidenční čtvrti s vesměs vilovou zástavbou (Vilová) a třetí školou v nezávislé správní oblasti na samém okraji Prahy (Starousedlická). Z těchto škol se účastnicemi výzkumu stalo sedm učitelek. Dále jsme se kvůli různorodosti škol rozhodli zapojit učitelky z mimopražské školy. Vzhledem $\mathrm{k}$ dostupnosti jsme kontaktovali základní školu v menším městě. $\mathrm{V}$ tomto městě jsou čtyři běžné základní školy, z nichž tř̌i ředitelé odpověděli na zaslaný dopis s na-

Tab. 1. Charakteristika učitelů zapojených do výzkumu

\begin{tabular}{|c|c|c|c|c|c|}
\hline Škola & $\begin{array}{c}\text { Jméno } \\
\text { učitelky }\end{array}$ & Zkratka & Ročník & $\begin{array}{c}\text { Praxe } \\
(\mathrm{v} \text { letech })\end{array}$ & Poznámky \\
\hline \multirow{3}{*}{ Vilová } & Monika & M & 2. & 15 & $\begin{array}{l}\text { Po tříměsíční zkušební } \\
\text { době odešla ze školy. Před- } \\
\text { tím více než } 13 \text { let působila } \\
\text { na venkovské } Z S ̌ S\end{array}$ \\
\hline & Karolína & K & 3. & 2 & $\begin{array}{l}\text { Neaprobovaná pro 1. stu- } \\
\text { peň ZŠ, studuje doplňující } \\
\text { pedagogické studium }\end{array}$ \\
\hline & Ivana & I & 5. & 5 & - \\
\hline \multirow{2}{*}{ Společná } & Ema & E & 2. & 12 & - \\
\hline & Lucie & $\mathrm{L}$ & 5. & 15 & - \\
\hline \multirow{2}{*}{ Starousedlická } & Nada & $\mathrm{N}$ & 5. & 12 & +8 let praxe učitelky v MŠ \\
\hline & Františka & $\mathrm{F}$ & 3. & 12 & 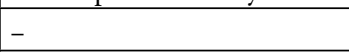 \\
\hline \multirow{2}{*}{ Říční } & Jana & $\mathrm{J}$ & 4. & 7 & - \\
\hline & Simona & $S$ & 4. & 10 & - \\
\hline Šišková & Alena & A & 3. & 3 & - \\
\hline
\end{tabular}


bídkou účasti na výzkumu odmítavě, jedna škola (Říční) se k výzkumu přihlásila. Reeditel této školy nabídl účast na výzkumu všem učitelům 1 . stupně $Z \check{S}$, dvě z učitelek $s$ účastí souhlasily. Poslední učitelka byla cíleně vybrána z pražské školy (Šišková), kde se vzdělává relativně hodně žáků ze sociokulturně znevýhodněného prostředí.

Účastnicemi výzkumu bylo tedy celkem 10 učitelek 1 . stupně $Z S ̌$, přičemž jedna z nich se projektu účastnila pouze tři měsíce. Učitelky se lišily délkou své praxe, pracovními zkušenosti a ročníkem, ve kterém působily (tab. 1).

\subsection{Metody a postupy sběru dat}

V zájmu co nejkomplexnějš́ího popisu hodnocení na 1. stupni Z $\breve{S}$ jsme použili více metod sběru dat, přičemž jsme se snažili data získávat $\mathrm{v}$ přirozeném prostředí „z první ruky“ (viz Bassey, 1999), tj. ve škole, resp. ve školní třídě.

Sběr dat $\mathrm{v}$ tomto výzkumu sestával z několika fází a metod:

a) pozorování ve školních třídách za použití pozorovacích archů, terénních poznámek, př́ípadně audiozáznamů a videozáznamů;

b) hloubkové polostrukturované individuální rozhovory s učiteli;

c) obsahová analýza, resp. analýza dokumentů, tj. všech artefaktů, které vznikly v pozorované hodině a bylo možné je po hodině ofotit (např. zápisy do sešitů, pracovní listy, zápisy na tabuli, hodnoticí dotazníky, sebehodnoticí dotazníky; přípravy na pozorovanou hodinu, pokud je učitel poskytl; další materiály, o kterých se učitel zmínil v rozhovoru a měl je $\mathrm{k}$ dispozici, tj. např. opravené písemné práce, dotazníky, učitelovy záznamy hodnocení, žákovská portfolia, žákovské diáře, týdenní plány).

\section{Pozorování}

Pozorování bylo vždy první fází sběru dat na každé škole. Učitelky byly požádány, aby vedly hodiny obvyklým způsobem. Jako důvod našeho pozorování jim bylo sděleno, že nás zajímá kvalita výuky. Účelem pozorování bylo zaznamenat a popsat veškeré způsoby práce $s$ cíli, které se $\mathrm{v}$ hodině vyskytnou. Jelikož nebylo od začátku vždy zřejmé, zda položená otázka, nastíněná učební úloha, situace ve třídě apod. mají něco společného $s$ jevy, které jsme chtěli sledovat, jednalo se o široce zaměřené pozorování - do záznamového archu jsme se snažili zaznamenat veškeré jednání učitele a žáků, druhy aktivit, dělali jsme si poznámky ke klimatu třídy, prostoru učebny apod. Pozorování bylo nejdříve deskriptivní. Po uzavření první série pozorování (po této fázi jsme měli hotové u každé učitelky pozorování dvou vyučovacích hodin a rozhovor $s$ ní) jsme provedli analýzy získaných dat. $\mathrm{V}$ průběhu první reflexe analýzy dat jsme si kladli otázky o struktuře, vztazích a organizaci dat. Druhá fáze pozorování byla tedy pak již více zaměřená (srov. Švařiček \& Šed’ová, 2007, s. 149). Videozáznamy z některých hodin (7) nám potom umožnily zaměrit pozorování na specifické jevy (např. obsah hodnoticích výroků v rámci vrstevnického hodnocení a sebehodnocení; konkrétní formulace učitelů při uzavírání 
Tab. 2. Ukázka části dotazovacího schématu týkající se vzdělávacích cílů

\begin{tabular}{|ll|}
\hline 1. & $\begin{array}{l}\text { Stanovujete si před hodinou prvouky/vlastivědy/literární výchovy (dále LV) cíle, } \\
\text { kterých chcete v hodině dosáhnout? }\end{array}$ \\
\hline 1.1. & Stanovujete cíle hodin pro žáky, pro sebe, nebo obojí? \\
\hline 2. & Sdělujete žåkům, co je cílem hodiny? Proč? \\
\hline 2.1. & Jak často? \\
\hline 2.2. & Jakým způsobem jim cíle sdělujete? \\
\hline 3. & Přesvědčujete se nějakým způsobem, že žáci cílům rozumějí? \\
\hline 4. & .. \\
\hline
\end{tabular}

hodiny apod.). U osmi z deseti učitelek jsme pozorovali pět vyučovacích hodin, u ostatních dvou tři vyučovací hodiny. Tři pozorované hodiny jsme nakonec vyřadili z analýzy, protože jejich náplní bylo učivo, které nelze označit jako učivo sociálně-humanitní (jednalo se o hodiny zeměpisně zaměřené).

Pro pozorování byl připraven speciálně upravený záznamový arch, který obsahoval identifikační údaje o škole a třídě, doplňující informace, které poskytl učitel, doplňující informace pozorovatele. Dále zde byl vyhrazený prostor pro záznam činností žáků a učitele: čas, činnost učitele, činnost žáků, komentár a otázky. Do záznamového archu se také zapisovaly odkazy na další materiály, které byly $\mathrm{k}$ hodině získány (fotografie zápisů na tabuli, fotokopie žákovských prací aj.).

$V$ druhé fázi pozorování jsme se zamèřovali především na to, jak učitel sděluje žákům cíle a obsah hodiny, zda se $\mathrm{k}$ cílům $\mathrm{v}$ průběhu hodiny a $\mathrm{v}$ jejím závěru vrací, jak sděluje žákům kritéria pro vypracování práce a jak s kritérii pracuje po skončení práce a jejím vyhodnocení, jak jednotlivé části hodiny souvisejí s výukovým cílem, jaké činnosti mají zpětnovazební a hodnoticí funkci a jak probíhají.

\section{Rozhovory s učiteli}

Další metodou, kterou jsme použili, byl polostrukturovaný rozhovor, který vycházel z předem připravených témat a otázek. Rozhovory byly zaměřené šiřeji, než je vymezení tohoto článku. Tazatel si rozhovor připravoval na základě předpřipraveného schématu, přičemž výsledná koncepce tazatelského schématu se odvíjela od specifik vybraných škol, zkušeností učitelů a zahrnovala také otázky směřující k pozorovaným hodinám a výukovým artefaktům.

Rozhovory byly vedeny individuálně a trvaly 20-40 minut.

Zpětná vazba $\mathrm{k}$ pozorování a vyvstalé otázky byly diskutovány $s$ vyučujícími neprodleně po výuce. Tyto kratší rozhovory nebyly zaznamenávány na diktafon, odehrávaly se na chodbách, o přestávkách apod. Všechny se potom staly součástí terénních poznámek.

\section{Analýza dat}

Analýza dat probíhala ve dvou následujících krocích. 


\section{a) Systematizace datových souborů a transkripce dat}

Veškerá data byla systematicky ukládána a zálohována. Takto byly $\mathrm{k}$ záznamům z pozorovaných hodin přiřazeny fotografie zápisů na tabuli, ukázky žákovských prací, př́prava učitele na hodinu aj. U některých hodin, z nichž byly zároveň pořízeny audio- či videonahrávky (snažili jsme se pořídit alespoň jednu nahrávku hodiny u každé učitelky, abychom získali přesné a úplné přepisy dialogů probíhajících ve trrídě), jsme v určité fázi přistoupili $\mathrm{k}$ transkripci vybraných částí hodiny, které byly relevantní vzhledem k výzkumné otázce.

\section{b) Kódování a kategorizace dat}

Pro kódování, kategorizaci a konceptualizaci dat z pozorování byl využit softwarový program pro kvalitativní analýzu dat MAXQDA. Nejdříve jsme v datech identifikovali významové jednotky a ty jsme následně pojmenovali kódy. První kódy byly průběžně přejmenovávány, precizovány, slučovány, hierarchizovány apod. $\mathrm{V}$ některých prrípadech byly jako kódy použity odborné termíny (např̀. individualizovaná zpětná vazba) nebo in vivo kódy, které reprezentují výrazy, jež použili sami respondenti (napr. pravidlo tří).

Průběžnou hierarchizací kódů byly vytvářeny obecnější kategorie. Výsledkem byl tzv. kódovací systém, v jehož rámci byla zpracována všechna získávaná data.

$\mathrm{Na}$ kódování navázala analýza a interpretace každého př́ípadu zvlášt (deskriptivní př́stup), poté byla použita „cross-case“ analýza (Yin, 2009, s. 156), jejímž cílem je určit podobnosti a odlišnosti v jednotlivých príípadech. $V$ tomto článku prezentu- jeme především výsledky výzkumu, který poskytla cross-case analýza.

\section{VÝSLEDKY VÝZKUMU}

Dílčí výsledky výzkumu zaměřené na výukové cíle budeme prezentovat $\mathrm{v}$ chronologickém pořadí, tak jak se vyskytují během výuky - od stanovování cílů v úvodu hodin až po závěrečné reflexe. $\mathrm{V}$ textu budeme citovat různé datové úryvky, které budou vždy označeny zkratkou vyjadřující případ, metodu shromažd’ování dat a zdroj dat. Jelikož jednotlivé př́pady jsou představovány jednotlivými učitelkami, bude první písmeno zkratkou jejich jména (viz tab. 1), další písmeno označuje, zda se jedná o rozhovor (R), pozorování (P) nebo výukový artefakt/materiál (M).

\subsection{Stanovování výukových cílů a seznamování žáků s nimi}

Přestože obecně didaktické, normativní zdroje explicitní stanovování cílů pro žáky doporučují (např. Pasch et al., 2005; Kalhous, Obst et al., 2009; Skalková, 1999; Vališová \& Kasíková, 2011), v našem výzkumu jsme se víceméně nesetkali s tím, že by učitelka cíle ve smyslu očekávaných znalostí a dovedností žákům sdělovala. U dvou učitelek se vyskytla relativně konkrétní informace o záměru vyučovací hodiny, napr.:

U: Co maji obrázky společného?Ž: Že jsou vytǐ̌těné. $\check{Z}:$ Že pomáhají. U: Je to tak, že na v̌sech tèch obrázcích je někdo, kdo ostatním pomáhá. Dneska se budeme bavit právě o vzájemné pomoci, o vnimáni druhých. 
Chtěla bych, abyste se zkusili navzájem vnimat a abyste se zamysleli, jak si mezi sebou pomáhat... (KP)

$Z$ rozhovorů $s$ učitelkami je patrné, že pojem výukový cíl jim není neznámý a rozumějí jeho významu (až snad na jednu výjimku - viz níže). Dokonce připouštějí, že by mohl být užitečný: že prostě si mưžu odškrtnout, nebo ne, a ty dèti taky, pro ně je to samozŕejmě jasnèjší, oni čím jasnèji vidí, co maji dělat, tím je to pro ně jednodǔší, že védí, mám hotovo, nemám hotovo (...) čim jasněji, konkrétněji jim to reknete, tím líp se to pak kontroluje (NR), dávají dokonce najevo určitý „pocit provinilosti“, že je nemají formulované, respektive je nesdělují žákům: no, ne vždycky je stanovuju, to se priznám (NR).

Jediná učitelka Monika $\mathrm{v}$ rozhovoru zaměňovala obsah pojmu výukový cíl $s$ pojmy výukové metody, aktivity, napr.: T: Jak sdèlujete žákưm v prvouce, co je cílem hodiny? U: Když třeba vím, že v té prvouce budu dávat tu desetiminutovku. To jsou, já vám to třeba ukážu, to jsou takové listečky, $k d y$ jsou odpovédi třeba jedna až pět nebo jak ríkám ten obrázek a dokresluji, tak vi, že je to na známku, že hodnotím a mám body.

$\mathrm{Z}$ rozhovorů je patrné, že učitelky přirozeně uvažují o cílech př̀i výběru učiva s ohledem na potřeby a možnosti žáků: $̌$ Reknu si, (...) kam by jako měl ten prümèrnej žák dojit, tak to je ten cíl jako (FR). Při výběru cílů odkazují na školní vzdělávací program, tematické plány nebo učebnice: $j a ́$ si vždycky vytahuju z každé kapitoly to, co bych chtèla, aby si odnesli, aby si pamatovali. Co si myslím, že z té páté trídy je pro ně dìležité. (...) Néjaký minimálni obsah informaci, kte- rý bych chtěla, aby si pamatovali (IR). Můžeme uzavřít, že učitelky většinou o cílech přemýšlejí a pro sebe si je dobře uvědomují, necítí však potřebu si je napsat např. do přípravy na výuku a sdělovat je žákủm.

Zajímavým poznatkem bylo, že $\mathrm{v}$ rozhovorech učitelky nezmiňovaly, že usilují o dosažení afektivních vzdělávacích cílů. Ačkoli bylo z jimi realizované výuky zřejmé, že jim jde o to, aby žáci rozvíjeli i tuto oblast, především v oblasti kompetencí sociálních, personálních a komunikativních, v rozhovoru to neuváděly. Také neuváděly afektivní cíle přímo se vážící $\mathrm{k}$ učivu, ač tomu tak v některých prýpadech být mohlo (např. učitelka Ema usilovala o to, aby si žáci uvědomovali př́nos vynálezů pro jejich život a vážili si práce vědců, učitelka Lucie chtěla, aby si žáci uvědomovali důležitost rodinných vazeb a význam slavení rodinných svátků, apod.). Zdá se, že učitelé předpokládají, že se od nich očekává především to, že žáky vybaví patřičnými znalostmi, prípadně dovednostmi.

Dalším poznatkem našeho výzkumu je, že ačkoli v pozorované výuce nebyly sdělovány cíle výuky, ve většině hodin jsme zaznamenali, že učitelky sdělují žákům téma hodiny a velmi často i metody, postupy práce, které budou v hodině použity: $M y$ se dneska posuneme dál. Dneska budeme dèlat husitské války. Formou skupinové práce se budete učit navzájem. (IP); Takže my si dáme mluvni cvičeni, zadáme si dalši a pak se budeme věnovat Karlu IV., nejslavnèjsimu Lucemburkovi. A zadáme si projekt, který tady začneme, a pak si to dodèláte doma. Pisemku, jak jste se na ni ptali, tak to budou premyslovstí králové... (NP); Nesdèluju jim úplně prímo jako 
cile, ale spiš to téma jako takový (FR); Spis jako ríkám tu nápln (SR); Vždycky si řekneme, co budeme dèlat ten den v tom prededmèté, neformuluju to vyloženě tak, že dneska řeknu, že chci, abyste se naučili... (ER).

$\mathrm{V}$ některých prípadech učitelky obsah hodiny žákům nesdělují záměrně, aby probudily jejich zvědavost a zájem. Připravují pro žáky různé aktivity, které končí odhalením tématu. $\mathrm{K}$ odhalení dochází v různých fázích hodiny: Vždycky napišu nèjakou zprávu, co nás čeká, nebo jim to zpestrím něčím, ñákým kvizem. (ER); Podle binga jste mohli zjistit, o čem bude dnešni hodina. Co asi ted'budeme dělat? Ž: Povidat si o Vánocích. (LP); U: Nás dneska čeká... (dramatická odmlka) Uvidime v rannim dopise... (Hraje prekvapeni) Co to tu máme? Žž: Mapu Čské republiky. U: Mapu České republiky? Co tam vidime? Ž: Barvy. $\mathrm{U}:$ Barvy? Co nás asi čeká? Ž: Barvy svèta. $\check{Z}$ : Barvy na mapě. Ž: Jak se zakreslujou mapy, domečky. U: To už asi umime. Ž: Jak se orientujeme v prírodě. Ž: Jak se orientovat podle mapy... U: Já vám to ted'nereknu, uvidíte za chvili, kdo mél pravdu. (FP); U: To, co budeme dnes dělat, je zatím tajemství. Doufám, že na to príjdete sami. (LP).

Tři z učitelek, $\mathrm{z}$ toho dvě pravidelně, využívají pro seznámení žáků $s$ obsahem výuky a organizací školního dne tzv. ranní dopisy. Většinou jsou ranní dopisy stručné a zaměrují se pouze na názvy předmětů, respektive i plánované postupy výuky, prrípadně jsou sdělena obecnějšś témata výuky. Děti tak získávají orientační body pro průběh učení (advanced organizers; Marzano et al., 2001).

\subsection{Jak se cíle projevují v učeb- ních úlohách}

Podobně jako v úvodu vyučovacích hodin i v jejich průběhu zůstávají cíle skryté.

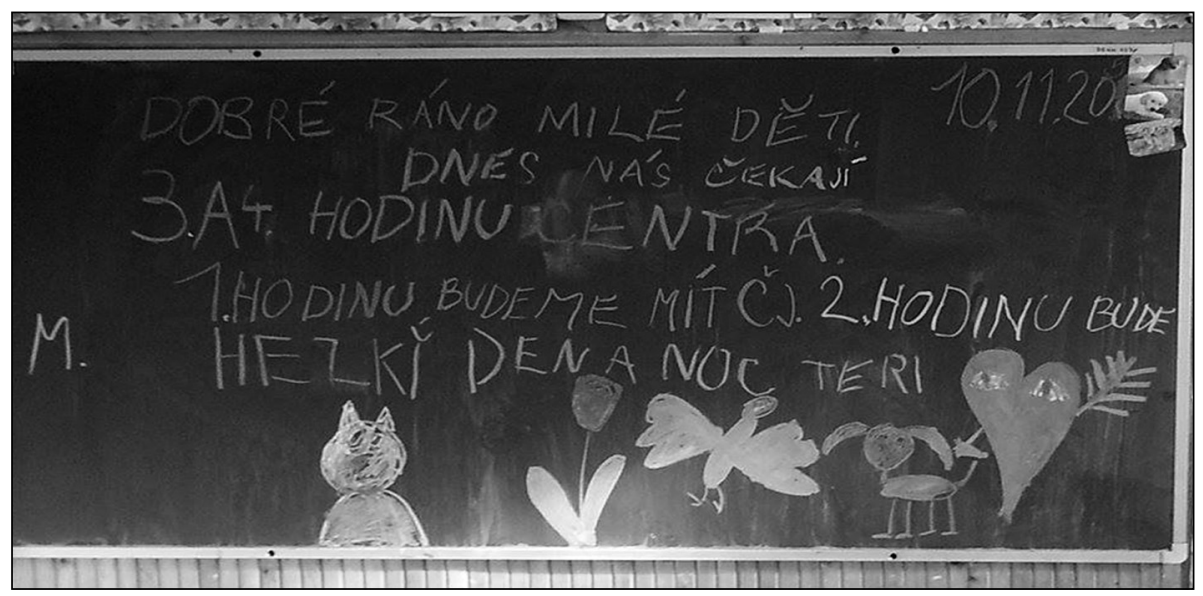

Obr. 1. Ranní dopis připravený žákyní ve spolupráci s učitelkou (EM) 
To však neznamená, že by nebyly př́itomny.

Jelikož často nebyly cíle hodin explicitně formulovány, pokusili jsme se je pochopit z obsahu učebních úloh, ačkoli jsme si vědomi toho, že toto „zpětné vymezení“ cílů může být někdy nepřesné. $O$ tématu hodiny se dozvídáme ze sdělení učitelek žákům a $\mathrm{z}$ jejich př́prav na hodinu, kde je téma často uvedeno (viz např. obrázek 2, kde se téma shoduje s názvem kapitoly v učebnici), konkrétní cíl žádná ze získaných príprav neobsahovala. ${ }^{6}$

$\mathrm{Z}$ některých hodin je patrné, že ačkoli učitelky žákům cíl hodiny nesdělují, mají jej promyšlený a zadávají žákům takové učební úlohy, které jsou s jejich záměrem $\mathrm{v}$ souladu. Př́ikladem může být třeba př́iprava na hodinu učitelky Lucie, která $\mathrm{v}$ prrípravě sice cíl neformuluje, ale do př́ipravy si vpisuje poznámky typu: Dokázat, jak na to prìsli! Najdi presnè vèty, které to dokazuji (LM). Z pozorování pak bylo patrné, že učitelka má cíl (Žáci vyhledají $\mathrm{v}$ textových materiálech důkazy pro svá tvrzení) na paměti a usiluje o to, aby dosažené dovednosti dosáhli všichni žáci:

U: Proč bylo počasi pro maminku a pro tatinka hnusné? (K žákovi, který si neví rady s odpovědí do pracovního listu.)

Ž: To je hrozně těžký! (povzdech)

$\mathrm{U:} \mathrm{Co} \mathrm{je} \mathrm{hrozně} \mathrm{těžký?}$

Ž: Jednička a čtyrkka.

U: To višs... Proto máte ten text, abyste to tam kdyžtak našli. Neni tam otázka, na kterou byste v textu nenašli odpovéd.' (Další dvě dívky bezradně vzdychají.) Tam je to prímo napsané, holky! (K chlapci, který se nemůže „hnout z místa“.) Pojd'sem, Pavko. Préčti si tenhle odstavec, odtud... (Chlapcovi tato podpora stačí a nachází v textu věty odpovědi na položenou otázku.) (LP)

Dalším prííladem souladu cílů (kognitivního a afektivního) hodiny (Žák zdůvodní, proč byl vynález důležitý. Žák vyjádří, proč si váží daného vynálezu.), učebních úloh a průběžného hodnocení může být př́klad dialogu učitelky se skupinou žáků:

Situace: Ema prochází mezi žáky a poskytuje jim podporu pro splnění úkolu. Žáci sedí v tzv. hnízdech, někdy tedy dochází ke komunikaci se skupinou žáků.

U: Tak to tam napiš, proč to byl dùležitý vynález.

Ž: Jsem ráda, že se vynalezl fén.

$\mathrm{U}:$ Emičko, ty jsi ale nenapsala, proč jsi ráda, proč to bylo dobré, že to bylo vyrobené... Napis to tam. Radku, tobè tam chybi ješté doba, kdy to bylo vyrobené... Ano, ale ty jsi nenapsala, proč to byl vynález, proč to bylo dobré...

$\check{Z}:$ Nevím, proč jsem ráda, že ten $C a-$ dillac byl vyrobený.

$\check{\mathrm{Z}}$ : A to bylo proni auto?

$\mathrm{U}: \mathrm{Ne}$, třeba Emička má Ford, ale ty más Cadillac vyrobený v roce 1908. Jsou rüzné značky, treba...

Ž: My máme škodovku.

U: Vy máte škodovku? A jste rádi, že ji máte? Proč?

Ž: Že můžeme jezdit na výlety.

${ }^{6}$ Př́ípravy na hodinu se lišily svým obsahem i formou, některé byly relativně podrobné (viz obr. 2), jiné stručné, či je učitelky neměly vůbec zpracované: Je to pro mé zbytečné, mám to v hlavě (MR). 
PRVOUKA

TÉMa: SOUZIก' MZ̆TDUE PRAVIDLA

(1) KRUH $\Rightarrow$ fímenka s $1030 D A$ - serlarle seorr.... - pak micer? we cuer re Akládá xe

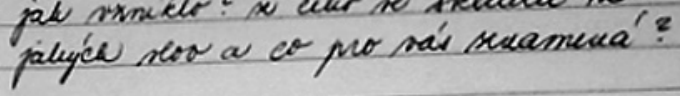

$\Rightarrow$ byla max̌ nemé widy intrdaa' a kdy ne, jal a la meminde projertrala?

$\rightarrow$ SVOBODA - kardy' in' mive dielal or elew?

(2) HRA NA KOVZELNIKA $\Rightarrow$ reflew - citilli joll se mtidne? of nas longmale a omenoralos |PRAVIDCA] - jaká praxidla máme ne kídie? i üsw mám jománaj...

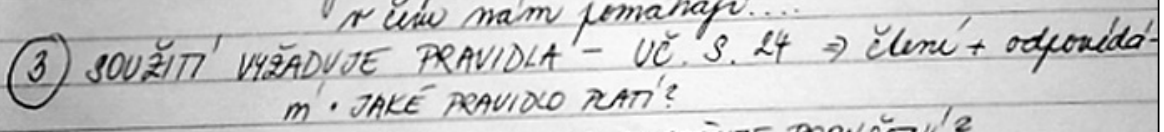

- KOHO NEBO co ohrozUde PORUSÉal'?

- odkud se vatco? de nekde napstné?

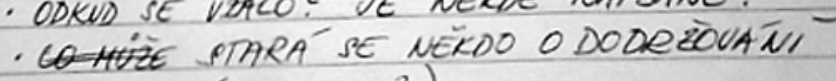
PRAVIDLA (KONTROLU?)

- CO MUEE UDELAT TOMU, KDO PRAVIDLO NEDODEZUNE?

(4) SXUPINEY $\Rightarrow$ NAPISTE EE KATEGORIIT MULlelady pravidee INA KARTICEACH - na prowaty

er tychow méti detal:

(5) KRUH - Cten' pranidel + nyberle in jeduo parider bleve ne raw neiné li'm' $\Rightarrow$ KovaENIKA $\rightarrow$ proc in archañoreo?

Obr. 2. Př́íprava na hodinu (FM)

118 
$\mathrm{U}:$ A tady můžeš tedy napsat, že je dobře, že lidi se mohli vozit, mohli jezdit na výlety.

Ž: Jak to mám napsat?

U: Takble to napiš, jak to ríkám.

$\mathrm{U}:$ Aničko, nenapsala jsi, proč jsi ráda, že byl vyrobený fén. (počká)

Ž: Aby si mohli lidi usušit vlasy.

U: Ano, presně tak. (učitelka odchází, dívka píše) (EP)

Ve větším množství hodin jsme ale identifikovali úlohy, které se prŕmo neváží $\mathrm{k}$ cíli či tématu hodiny nebo se od něho odchylují. Tyto hodiny pak nesplňují požadavek soudržnosti, který je podpořen teoriemi smysluplného učení (Ausubel) a generativního vyučování a učení (Wittrock) (citováno dle Janík et al. 2013, s. 118).

$\mathrm{Z}$ výše uvedených dvou ukázek je zřejmá značná snaha učitelek, aby všichni žáci dosáhli cíle v maximální možné míře (srov. mastery learning - Bloom, 1984; Guskey, 2007; Zimmerman \& Dibenedetto, 2008; Laufková, 2016). Nemůžeme to ale říct o všech sledovaných hodinách (a učitelkách). Nedá se ani říct, že podrobná př́iprava zaručuje dostatečnou konzistentnost výukových cílů a př́ležitostí pro žákovo učení. $\mathrm{V}$ jedné hodině např́klad probíhají 32 minut činnosti, které se $\mathrm{k}$ hodině (Funkce pravidel ve společnosti) vážou jen velmi volně (úvodní aktivita v kruhu: Co dobrého jsi dnes udělal pro někoho jiného? / 7 minut; řešení přesmyčky / 2 minuty; brainstorming, co to znamená svoboda / 13 minut; hra, jen velmi volně vázána na téma hodiny / 10 minut). Jádrové aktivity probíhají až ve zbylém čase, tedy v rámci 13 minut. Tento omezený čas neumožňuje zprostředkovat žákům učivo do hloubky, i když „výuka je rozehrána“ velmi slibně - žáci v posledních 13 minutách četli $\mathrm{z}$ učebnice funkce pravidel a potom ve skupině $\mathrm{k}$ přidělené funkci vymýšleli př́klady. Analýza jejich odpovědí a prohloubení a upevnění učiva však vzhledem $k$ nedostatku času byly spíše povrchní:

$\check{Z}:$ Já tady mám nadpis pravidla, která zajistuji bezpečnost. Máme tu... Jezdime na zelenou...

U: Je to pravda, výbornè. Tak dalši skupina.

Ž: Pomáhají řešit spory. A tady je odpovèd' jenom rodiče.

U: Napsali jste, kdo je zajištuje, ale chtélo by to vymyslet, jaké by to bylo pravidlo. To uděláme kdyžtak prì̌stè... Já jsem ráda, odvedli jste perfektni práci. (FP)

$\mathrm{V}$ př́pravě na tuto hodinu Františka relativně podrobně popisuje jednotlivé učební úlohy, ale př́íprava neobsahuje žádný časový odhad. $\mathrm{V}$ prŕípravě na hodinu není uveden výukový cíl (FM). Domníváme se, že promyšlení vzdělávacího cíle a jeho explicitní formulace (at se jedná o cíle z domény kognitivní, afektivní či psychomotorické) by mohlo vést $\mathrm{k}$ efektivnějšímu plánování učebních úloh včetně poskytnutí dostatečného časového prostoru pro ukotvení vzdělávacího obsahu $\mathrm{v}$ paměti žáků.

$\mathrm{V}$ jiné hodině vlastivědy učitelka sdělila žákům, že se budou věnovat orientaci v mapě, ale nakonec se opakování učiva $\mathrm{z}$ tohoto tématu týkalo jen 5 minut. $\mathrm{V}$ ostatním čase se žáci věnovali tématu státní symboly či řízení státu. Hodina měla nejasnou strukturu (SP). 
Ani sdělení tématu a průběhu hodiny tedy nezaručuje, že se tak bude hodina skutečně naplňovat. $\mathrm{Na}$ druhou stranu i hodiny, kde není sdělen cíl, mohou mít jasnou strukturu a poskytovat žákům dostatek prríležitostí, aby výukový cíl zamýšlený učitelem naplnily.

\subsection{Jak se cíle projevují $v$ hodno- tících procesech}

I když výukové cíle nebyly zpravidla $\mathrm{v}$ pozorovaných hodinách explicitně vyjádřeny, bylo možné je rekonstruovat při probíhajících hodnoticích procesech. (Hodnocení zde chápeme hodně široce od bezprostředních reakcí na výkony žáků až po podrobnou písemnou zpětnou vazbu.) Jak bylo naznačeno výše, nejzřetelněji při používání kriteriálního hodnocení, ale napřr. také při používání rychlé zpětné vazby a vávěrečných shrnutích a reflexích.

\section{Soulad a nesoulad vzdělávacích cílů a hodnoticích procesů}

Prostřednictvím hodnoticích procesů by měl učitel zjištovat, zda a $\mathrm{v}$ jaké míre došlo $\mathrm{k}$ naplnění výukových cílů, a to až po úroveň jednotlivých dětí. Toto zjištění má význam nejen pro něj (do značné míry řídí jeho další plánování a realizaci výuky včetně podpory žáků, u kterých se dozvěděl díky hodnoticím procesům, že podporu potřebují), ale i pro žáka (dává mu zpětnou vazbu o tom, co se naučil a čemu je potřeba se dále věnovat, rozvijí jeho kompetenci k učení aj.). Hodnoticí procesy by tedy měly směřovat $\mathrm{k}$ hodnocení toho, co učitel jako cíl stanovil (např.
Gavriel, 2013; srov. s konceptem embedded assessment - in Shavelson et al., 2008).

$\mathrm{Z}$ analýzy sledovaných hodin můžeme konstatovat, že existují učitelky, které cíleně poukazují na souvislost očekávaných výsledků výuky a hodnocení, přičemž jedna ze sledovaných učitelek motivuje žáky $\mathrm{k}$ učení známkou, respektive vyhnutím se neúspěchu: Když budete $v$ hodině dávat pozor, tak si to [znalosti o přemyslovských knízatech] zopakujete a zapamatujete a dostanete pak dobrou známku $v$ testu (NP).

$\mathrm{Za}$ vhodnější považujeme prístup jiné učitelky, která dává najevo hodnotu získaných znalostí, když zdůrazňuje, že je samožrejmé, že se učivo žáci „potřebuji“" naučit a očekává to. Poukazuje na přirozené důsledky nízkého pracovního nasazení a nedostatku snahy a občas i na to, že díky hodnocení se žáci dozvědí, co se naučili a co mají udělat pro ještě lepší výsledky: My pak budeme dělat ještě dalši véci, takže ten, kdo nedává pozor a nespolupracuje, to [znalosti o husitských válkách] nebude védět a bude mu to chybèt. Jen na to upozornuji... Takže vezmeme to popořadè. Kdo mèl bitvu u Sudoměre? Ostatní poprosim, abyste si aspoň něco zapamatovali. Protože $v$ dalšim úkolu budete čerpat $z$ toho, co se ted'dozvite... Vy budete mit takový malý domáci úkol. Bude z pracovního sešitu... Vy doplnite to, co v textu chybi, a použijete to, co jste se dnes naučili. Pokud dokážete doplnit všechno, je to pro vás zpráva, že máte duiležité znalosti. Když něco bude někomu chybèt, znamená to, že se to musi doučit. (IP)

\section{Výukové cíle a kriteriální hodnocení}

Některé sledované učitelky pracují $s$ kritérii hodnocení s vědomím cíle hodiny 
a $\mathrm{v}$ logice probíraného učiva, a to různou měrou a různě efektivně, jiné s nimi nepracují vůbec. $Z$ explicitně uvedených kritérií hodnocení lze také vyvozovat implicitní cíle. Níze uvádíme několik ukázek dokumentujících používání kriteriálního hodnocení a přemýšlení o něm.

Nad’a zařazuje pravidelně do výuky tzv. mluvní cvičení $\mathrm{z}$ vlastivědy, $\mathrm{v}$ jejích hodinách jsme dále viděli použití kritérií při zadání domácího úkolu: vytvořit plakát o Karlu IV. Žáci dopředu znají kritéria a potom podle nich hodnotí své spolužáky. $\mathrm{V}$ rozhovoru

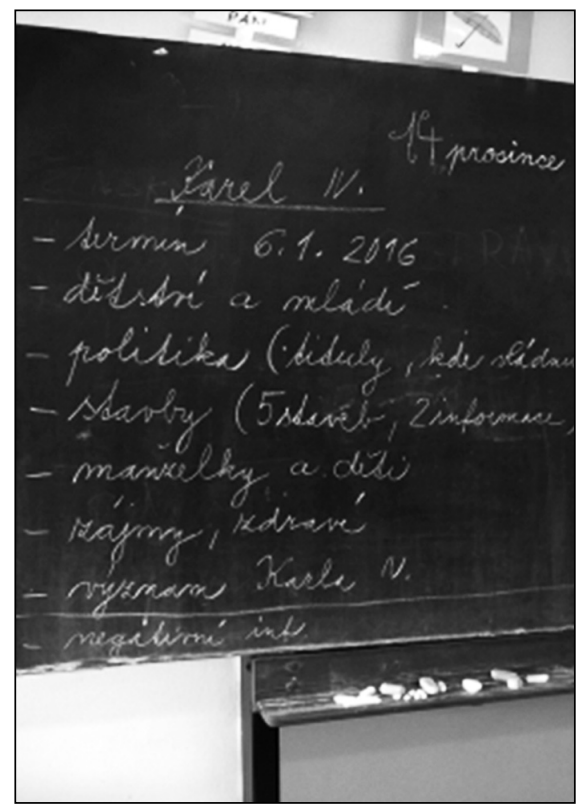

Obr. 3. Ukázka kritérií pro tvorbu plakátu z hodiny Nadi k tomu Nad’a říká: Tak vlastně úplně nejlepši je, když jim právè jasnè reknu, co já po nich budu na konci chtit, co by mělo být nějakým tím výstupem (NR).

Také Karolína ve svých hodinách používá kriteriální hodnocení: Dopředu jsem jim řekla, co je tam dìležité, na co si mají dávat pozor, jakým zpiosobem maji pracovat se šablonami, jakým zpiosobem šetriti s papirem, jakým zpiisobem vystrihovat a tak dále. A řekla jsem jim, že to jsou věci, které já potom budu hodnotit s tím, že zároveň jsem jim vysvètlila, proč to maji dèlat. $(\mathrm{KR})^{7}$

Uvedené př́klady ukazují, jak se v praxi kritéria prolínají s obsahovým zadáním úkolu. Za kritérium hodnocení lze označit napřr. včasné splnění úkolu.

\section{Rychlá (okamžitá) zpětná vazba}

Některé učitelky na 1 . stupni ZŽ používají techniky rychlé zpětné vazby. Tyto techniky umožňují získat odpověd' od více (všech) žáků najednou (a tím identifikovat, zda žáci porozuměli, či začít zjištovat, kde se žáci „ztratili“). Tyto techniky většinou vyhovují jak extrovertům (umožňují činnost a manipulaci), tak introvertům (mohou déle a v tichu přemýšlet).

Př́kladem rychlé zpětné vazby je např. ukázka z hodiny Lucie, která sledovala cíl „Žáci vyhledají v textových materiálech důkazy pro svá tvrzení". U: Kdo si mysli, že je to odpověd' $A, B, C$ ? (žáci zvedají ruce) Najdi présnè vètty, ve kterých je dokázáno, že je to $A$, a ukaž mi je v textu... Každý si dá prst na to misto $v$ učebnici. (LP)

\footnotetext{
${ }^{7}$ Pokud jsou slovně vyjádřená kritéria vztažena ke známce, lze to chápat jako kombinaci verbálního a číselného/ klasifikačního hodnocení, která může plnit jak sumativní, tak i formativní funkci.
} 


\section{Nesoulad mezi jádrem výuky a za- měřením hodnocení}

Některé učitelky občas hodnotí jiné znalosti či dovednosti než ty, které byly jádrem výuky (pojem viz Janík et al., 2013, s. 225). Většinou jde o slovní hodnoticí komentáŕe, které se netýkají jádrových činností z hlediska učiva sledovaného předmětu (především prvouky či vlastivědy), ale zaměřují se na hodnocení tzv. měkkých dovedností či na hodnocení jazykových jevů.

$\mathrm{V}$ některých hodinách byly při hodnocení neadekvátně upřednostněny osobnostní a sociální dovednosti před oborovými znalostmi a dovednostmi:

U: Pracovali jste moc hezky, a protože jste byli tak šikovný, tak tady mám ještě pár tèch bonbónkù a cokoládek, takže... Musite si zvolit, kdo sem může príjít a vzit si tu čokoládku. Ale je to na rozhodnutí trídy, kdo to bude. Kdo si zaslouži tu čokoládku? Tak co myslite, kdo tam pỉjde jako prvni? No, Ivanko, co mysliss?

ŽT: Mára, protože dal to s tim, já nevim, jak se to jmenovalo, ale to s tim hádej tu známou osobnost.

U: Hádej tu známou osobnost, takže Mareček? Jo? Je to tak? Tak Marečku, pojd,' Ivanka tè vybrala, dobre, tak to máme jednu čokoládku. Tak poděkuj Ivance.

ŽM: Děkuju.

ŽL: Já bych chtěla, aby Renča, protože ona je strǎsnè hodná.

U: To je pravda, to je pravda, protože Renča, to je naše zlato, vid? Výborně, ano? Tak Milenko, koho ty navrhujes?

ŽK: Já bych chtèla tam dát Máju, protože je hrozně milá a pučuje a pomáhá.
U: A pomáhá, tak Máji, pojd.' Mhmm. Tak Pedro, koho ty?

ŽP: Toma, protože je na něm hodně vidět, že i když mu něco nejde, tak se hodně snaží.

U: To je moc hezký, tak Pedro, pojd' teda... (FP)

\subsection{Jak se cíle projevují v závěru vyučovacích hodin}

Implicitní cíle se odhalují také v závěrečném zhodnocení, shrnutí či reflexi. Závěrečná reflexe je prokazatelně důležitým předpokladem, pro ukotvení výukového obsahu v dlouhodobé paměti žáků. $Z$ tohoto důvodu je doporučována jako důležitá didaktická zásada (Walberg, 1999; Marzano et al., 2000; Cotton, 2001).

Čtyři ze sledovaných učitelek se snaží shrnovat sledované učivo a získané znalosti a dovednosti ve většině svých hodin:

U: Co jsme si ríkali? Proč máme pravidla? Ž: Aby byla pohoda. Ž: Abychom žili $v$ miru. Ž: Aby nebyly úrazy. Ž: Aby někdo nenarazil do domu a nebylo to jako $v$ roce $2011 \ldots$ U: Pravidla zajištuji bezpečnost, pomáhaji nám $k$ tomu, aby se lidem žilo dobře, aby žili v miru, aby fungovala pohoda. (...) Dnes jsme $v$ hodinè dèlali... (opakuje činnosti). Máme pravidlo, že máme prestávku, abychom si mohli odpočinout, takže máme prestávku. (KP)

U: Do sešitu si napiste velkou bublinu Protektorát Čechy a Morava. Do pètilistku si napíseme, co jsme si o protektorátu Čechy a Morava zapamatovali. Ž: Prikrčit se a prežit za každou cenu. Ž: Hitler porušil Mnichovskou dohodu tím, že nás okupoval... 


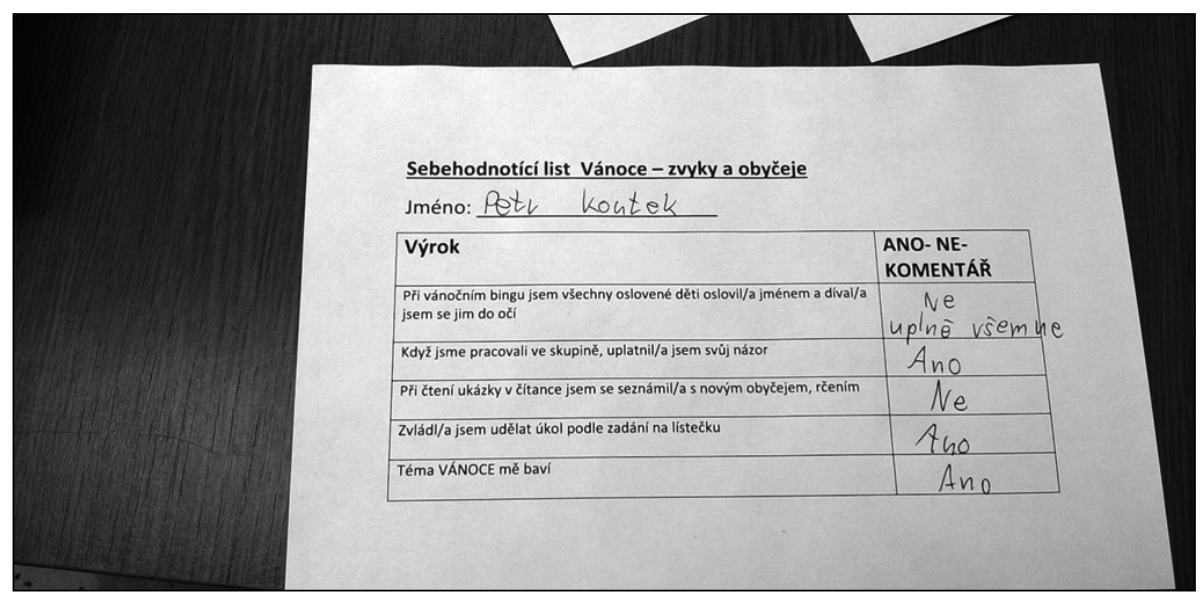

Obr. 4. Závěrečné žákovo sebehodnocení pomocí checklistů - kontrolních seznamů (LM)

(Žáci na tabuli zapisují to, co si zapamatovali. Musí to ale nejdřive schválit ostatní spolužáci.) (NP)

Některá závěrečná hodnocení jsou více zaměřená na obsah učiva, jiná jsou více zaměřená na rozvoj měkkých dovedností či zájem a aktivitu žáků (obr. 4).

$\mathrm{V}$ mnohých hodinách ale učitelky shrnutí či reflexi hodiny nedělají (podle jejich slov $\mathrm{z}$ důvodu nedostatku času) a hodiny končí „do ztracena“: Máte prestávku, kdo nemá hotovo, nevadi, dokoncí si to dalsí hodinu prí společné kontrole. (SP); Já vám napišu dèti z dnešni hodiny za práci v hodině jedničku do žákovský. Chcete to ted' nebo v pondèli? Žžž: $V$ pondělí. U: $A$ méjte se krásně (Žáci odcházejí ze třídy. Učitelka za nimi volá.) (LP); Kdo to nestihl, má to za domácí úkol. Zitra kontroluju! (NP).

Pro mnohé učitelky jsou zásadní zápisy do sešitu, které poskytují žákům a jejich rodičům shrnutí toho, co se v hodině žáci učili: např. Alena na základě návrhů dětí třídí informace, rozhoduje, které zapíše a které ne, upravuje formulace a zapisuje je na tabuli. Žáci si je opisují do svých sešitů:

U: Co jsme se naučili? Jak lidé žili? Ž: $̌$ Že pomáhaji zvirata. (U zapisuje na tabuli) Ž: Že si ochočili zviŕata. (U nezapisuje) Ž: Že prvni zviŕre bylo vlk. (U nezapisuje) Ž: Že jim krávy vozily vozičky. (U nezapisuje) U: A ještè bychom si tam méli zapsat, proč se lidé stěhovali z té puidy. Ž: Že nemohli tam už dál pěstovat. (U zapisuje na tabuli: Nebyla úroda - šipka - stěhováni - šipka síreni zemédèlstvî). (AP)

Další prŕklad je z hodiny Ivany:

$\mathrm{U}:$ Nám ještè zbývá posledni část. Zápis do sešitu. Co bychom si chtèli zapamatovat o sv. Václavovi? Ž: Že je patronem $\check{C} R$. Ž: $\check{Z}$ e ho vychovávala babička. Ž: Že ho zavraždili... Ž: Že byl prohlášen za svatého. U: Ještě bychom si méli pamatovat jednu informaci... Ž: Co si zapamatuješ ty, Honzo? U: Za- 
pište si ještě všichni to, co ríkala Markéta. Markéto, řekni jim to ještě jednou. (IP)

Některé zápisy do sešitů a/nebo reflexe jsou spíše formální (viz výše MP), některé jsou zaměřeny spíše obecně a děti se v nich soustředí na hodnocení aktivity své a spolužáků, schopnosti spolupracovat a další kompetence/dovednosti tohoto zaměření:

$\mathrm{U}:$ Jak se vám dneska pracovalo a jestli byste chtěli někoho pochválit. Ž: Já bych se chtěl pochválit za to, že jsem se hodnè hlásil. A chtěl bych pochválit také Šimona, protože jsme jediný tři, kdo se hlásili. Ž: Chtěla bych pochválit celou skupinu, protože se nám dobre pracovalo. (FP)

\section{DisKUSE}

Základním poznatkem naší studie je skutečnost, že s výukovými cíli jsme se setkávali v implicitní podobě. Protože zůstávaly nevyjádřené, bylo největší výzkumnou výzvou cíle identifikovat na základě nepřímých náznaků. I když cíle nebyly součástí běžného diskurzu komunity praktiků, neznamená to, že učitelky o cílech neuvažovaly. $\mathrm{K}$ tomuto závěru nás dovedly jejich odpovědi při individuálních rozhovorech. Hloubka jejich uvažování o cílech se ale lišila. Rozdíly jsme zaznamenali $\mathrm{v}$ míre uvědomování si cílů a v tom, do jaké míry $s$ cíli učitelky pracovaly při plánování, realizaci a reflexi výuky. $\mathrm{V}$ rozhovorech se překvapivě neobjevovaly výroky poukazující na směrování učitelů $\mathrm{k}$ rozvoji žákovských postojů a hodnot.
Implicitní cíle se vynořovaly při pozorování. Jednalo se o cíle kognitivní, v menší míre i afektivní a psychomotorické. Bylo to na začátku hodin při sdělování programu, v průběhu hodin při řešení učebních úloh a především při hodnoticích procesech včetně závěrečné reflexe. Nejžretelněji podle našeho názoru cíle „prosakují při používání kriteriálního hodnocení. Kritéria vlastně popisují, jak vypadá naplnění cíle, a tak se domníváme, že mohou cíle do jisté míry zastupovat.

Pokud jsou cíle, obsah a hodnoticí postupy v souladu (koherentní), přináší to významné pozitivní důsledky pro učení žáků (Seidel, Rimmele \& Prenzel, 2005). Naopak v prrípadě jejich nesouladu žáci nechápou, proč to či ono dělají, kam to směruje a obrazně řečeno se na cestě za poznáním ztrácejí. Tyto poznatky jsou v souladu s požadavkem soudružnosti při zprostředkování učiva podpořeného Ausubelovou teorií smysluplného učení či Whittrockovou teorií generativního učení (Janík et al. 2013, s. 118) a významně rezonují s myšlenkou organizátorů postupu při učení (Joyce \& Weil, 1972).

V souladu se závěry kognitivní psychologie (Sternberg, 2002) a psycholingvistiky (Kintsch \& van Dijk, 1978) je prijímán názor, že $\mathrm{k}$ porozumění textového sdělení dochází ve dvou rovinách: vyšší rovina se týká makrostruktury, organizace textu, globálního tématu a smyslu textu, nižší rovina pak navazování vět. Základem vy̌šsí roviny porozumění textu je predikce, ${ }^{8}$ tj. očekávání

\footnotetext{
${ }^{8}$ Od tohoto teoretického konceptu se odvíjí i význam predikce v testování čtenářské gramotnosti (PIRLS) nebo v programu Čtením a psaním ke kritickému myšlení (RWCT), odkud postupně přichází do praxe českých škol.
} 
př́ijemce týkající se obsahu nebo organizace textu. Nesoulad cílů a obsahů vzdělávání může mít za následek neporozumění na straně žáků. Př́íkladem zásadního nesouladu byly situace, kdy učitel něco jiného učil a něco jiného hodnotil.

Žákovo neporozumění lze chápat jako selhání procesu vyvozování/inferování správných závěrů. Pojem inference (Průcha, 1984; van de Velde, 1992) vyjadřuje procesy vysuzování nových informací $\mathrm{z}$ informací předložených $\mathrm{v}$ textu. Velký význam pro koherenci textu a její interpretaci je přičítán takovým prvkủm $\mathrm{v}$ komunikaci, které explicitně vyjadřují záměr/cíl produktora - učitele a jeho instrukce pro recipienta - žáka. Tuto funkci v našem výzkumu plnily výroky metatextové, např. "podivej se jestě jednou na posledni odstavec", metakomunikační, např. "položte si ve dvojici navzájem otázku... "či obsahující performativní slovesa vyjadřující postojovou modalitu, např. "přeju si, aby se vám dařilo vymyslet alespoň dva príklady toho, jak nám vynálezy pomáhaji v našem životě". Analýzou výroků učitele a jejich odezvy u žáků jsme dospěli k názoru, že zdokonalení práce $s$ výukovými cíli má potenciál přinášet žákům větší zisky z učení a celkově zkvalitňovat jejich vzdělávání.

Každopádně kvalita a způsoby práce $s$ cíli u zkoumaných učitelek byly velmi různorodé. V této souvislosti se jeví jako nutné individualizovat podporu učitelů, která by jim pomohla jejich práci s cíli zkvalitnit. Jako ideální se jeví doplnit vzdělávací kurzy či programy a interní (školní) podporu učitelů mentoringem proškolených učitelů vně školy, kteří se zaměřují na danou vzdě- lávací oblast / oborovou didaktiku (Hobson et al., 2015, s. 98). Zaměrit podporu učitelů více na oborově specifické jevy nám príijde jako stěžejní (argumentace viz Janík et al., 2013). Zvláště potřebné je to v oblasti sociálně-humanitního vzdělávání. Tato oblast má relativně málo zřetelnou vnitřní strukturu. To se projevilo v nesouladu cílů, obsahu výuky a hodnoticích postupů u některých hodin, někdy i v méně promyšleném a argumentovaném výběru učiva učitelkami. Zaměřit podporu učitelů na oborově-didaktickou oblast je také velmi důležité zvláště v oblasti primárního vzdělávání. Učitelé žáků na 1 . stupni ZŠ uči předměty širokého spektra, a to klade vysoké nároky na jejich oborové a oborově-didaktické znalosti $\mathrm{v}$ rámci mnoha oborů. Těm samožrejmě nemohou v plné míře dostát (Stará \& Krčmářová, 2014, s. 107). Právě individualizovaná podpora učitelů 1 . stupně $Z \check{S}$ v oblasti oborové didaktiky, která by propojila praktické zkušenosti a znalosti učitelů se systematickým pohledem na danou oborově-didaktickou problematiku expertů, by mohla $\mathrm{v}$ tomto směru přinést pozitivní změny.

\section{ZÁVĚR}

Za hlavní zjištění naší studie považujeme poznatek, že výukové cíle mohou poskytovat cenný nástroj pro plánování, realizaci i hodnocení učení a že je důležité, aby všechny tyto součásti byly koherentní. Výukové cíle tak mohou být pro žáky jakousi cestovní mapou, která jim nejprve ukazuje, kam se mají vydat, kde se v ten který okamžik aktuálně nacházejí, či zda cíle dosáhli. Aby se 
cestou neztratili, mají v učiteli zkušeného průvodce. Jeho úkolem je žákům předložit dobrou mapu, naučit je $\mathrm{v}$ ní číst, ukazovat, že ke stejnému cíli se mohou dostat různými cestami, a učit je ohlížet se zpět a reflektovat, jakou cestu zatím absolvovali a jaké zkušenosti a znalosti na ní získali.

Dalším důležitým poznatkem studie je skutečnost, že ačkoli texty české normativní pedagogiky obsahují požadavky explicitního stanovení výukových cílů a koncipování výuky na základě důsledné analýzy učiva, empirický výzkum přináší doklady toho, že tyto požadavky nejsou v praxi často realizovány. Domníváme se tedy, že je žádoucí budovat didaktiku více $s$ ohledem na reálný stav a potřeby praxe a zaměrit pedagogický výzkum více na zkoumání této reality.

\section{Literatura}

Bandura, A., \& Schunk, D. H. (1981). Cultivating competence, self-efficacy, and intrinsic interest through proximal self-motivation. Journal of Personality and Social Psychology, 41(3), 586-598. Bassey, M. (1999). Case study research in educational settings. Buckingham: Open University Press. Beneš, Z. (2009). Základ a aplikace. Dějepis mezi historickou vědou a školním vzděláním. Pedagogika. 59(2), 153-163.

Bloom, B. S. (1984). The search for methods of group instruction as effective as one-to-one tutoring. Educational Leadership, 41(8), 4-17.

Byčkovský, P., \& Kotásek, J. (2004). Nová taxonomie klasifikování kognitivních cílů ve vzdělávání: Revize Bloomovy taxonomie. Pedagogika, 54(3), 227-242.

Cauley, K. M., \& McMillan, J. H. (2009). Formative assessment techniques to support student motivation and achievement. Clearing House, 83(1), 1-6.

Clarke, S. (2005). Formative assessment in the secondary classroom. London: Hodder Murray.

Cotton, K. (2001). Effective schooling practices: A research syntesis. Portland: NREL.

Dvořák, D., Starý, K., Urbánek, P., Chvál, M., \& Walterová, E. (2010). Česká základni škola: víceprípadová studie. Praha: Karolinum.

Fenstermacher, G. D., \& Soltis, J. F. (2008). Vyučovaci styly učitelu. Praha: Portál.

Gavriel, J. (2013). Assessment for learning: A wider (classroom-researched) perspective is important for formative assessment and self-directed learning in general practice. Education for Primary Care, 24(2), 93-96.

Guskey, T. R. (2007). Closing achievement gaps: Revisiting Benjamin S. Bloom's „Learning for mastery". Journal of Advanced Academics, 19(1), 8-31.

Hattie, J. (2009). Visible learning: A synthesis of over 800 meta-analyses relating to achievement. London: Routledge.

Hattie, J., \& Timperley, H. (2007). The power of feedback. Review of Educational Research, 77(1), $81-112$.

Hobson, A. J., Maxwell, B., Stevens, A., Doyle, K., \& Malderez, A. (2015). Mentoring and coaching for teachers in the further education and skills sector in England. Dostupné z http://www.gatsby. org.uk/uploads/education/reports/pdf 
Chappuis, J. (2005). Helping students understand assessment. Educational Leadership, 63(3), 39-43. Chappuis, S., \& Chappuis, J. (2007). The best value in formative assessment. Educational Leadership: Informative Assessment, 65(4), 14-19.

Janík, T., et al. (2013). Kvalita (ve) vzděláváni: obsahově zaměrený prístup ke zkoumáni a zlepšování výuky. Brno: Masarykova Univerzita.

Joyce, B., \& Weil, M. (1972). Models of teaching. Prentice-Hall: New Jersey.

Kalhous, Z., Obst, O., et al. (2009). Školni didaktika. Praha: Portál.

Kintsch, W., \& van Dijk, T. A. (1978). Toward a model of text comprehension and production. Psychological Review, 85(5), 363-394.

Laufková, V. (2016). Formativni hodnoceni (Disertační práce). Praha: Univerzita Karlova.

Laufková, V. (2017). Formativní hodnocení v praxi základní školy. Pedagogika, 67(2), 104-124.

Mareš, J. (2013). Pedagogická psychologie. Praha: Portál.

Mareš, J. (2015). Tvorba př́padových studií pro výzkumné účely. Pedagogika, 65(2), 113-142.

Marshall, B. (2011). Testing English. Formative and summative approaches to English assessment. London: Continuum.

Marzano, R. J., Gaddy, B. B., \& Dean, C. (2000). What works in classroom instruction. Suite: McREL.

Marzano, R. J., Pickering, D. J., \& Pollock, J. E. (2001). Classroom instruction that works: Research-based strategies for increasing student achievement. Alexandria, VA: Association for Supervision and Curriculum Development.

McTighe, J., \& O'Connor, K. (2005). Seven practices for effective learning. Educational Leadership, 63(3), 10-17.

Morgan, D. L. (2001). Ohniskové skupiny jako metoda kvalitativního výzkumu. Boskovice: Albert.

Novotná, K., \& Krabsová, V. (2013). Formativní hodnocení: prípadová studie. Pedagogika, 63(3), 355-371.

Pasch, M., et al. (2005). Od vzdělávacího programu k vyučovací hodině. Praha: Portál.

Průcha, J. (1984). Nové teorie o „učení z textu“. Československá psychologie, 28(2), 143-151.

Sebba, J., Deakon Crick, R., Ju, G., Lawson, H., \& Harlen, W. (2008). Impact of self and peer assessment on students in secondary schools. Dostupné z https://www.gov.uk

Seidel, T., Rimmele, R., \& Prenzel, M. (2005). Clarity and coherence of lesson goals as a scaffold for student learning. Learning and Instruction, 15(6), 539-556.

Shavelson, R. J., Young, D. B., Ayala, C. C., Brandon, P. R., Furtak, E. M., Ruiz-Primo, M. A., et al. (2008). On the impact of curriculum-embedded formative assessment on learning: A collaboration between curriculum and assessment developers. Applied Measurement in Education, 21(4), 295-314.

Shepard, L. A., Rebello, N. S., Engelhardt, P. V., \& Singh, C. (2012). Assessment lessons from K-12 education research: Knowledge representation, learning, and motivation. 2011 Physics Education Research Conference (s. 73-76).

Scheerens, J., \& Bosker, R. J. (1997). The foundations of educational effectiveness. Oxford: Elsevier Science. 
Skalková, J. (1999). Obecná didaktika. Praha: ISV.

Slavík, J., Janík, T., Najvar, P., \& Knecht, P. (2017). Transdisciplinárni didaktika: O učitelském sdíleni znalostí a zvyšování kvality výnky napríč obory. Brno: Masarykova univerzita.

Stará, J., \& Krčmárová, T. (2014). Uživání nových učebnicových materiálů učiteli 1. stupně ZŠ. Pedagogická orientace, 24(1), 77-110.

Stará, J., \& Starý, K. (2017). Studie výuky dějepisného učiva na 1. stupni ZŠ. Pedagogická orientace, 27(1), 6-29.

Starý, K. (2006). Efektivní výnkové strategie (Disertační práce). Praha: Univerzita Karlova.

Sternberg, R. J. (2002). Kognitivni psychologie. Praha: Portál.

Stodolsky, S. S. (1988). The subject matters: Classroom activity in math and social studies. Chicago: University of Chicago Press.

Straková, J., \& Slavík, J. (2013). (Formativní) hodnocení - aktuální téma. Pedagogika, 63(3), 277-284.

Švaříček, R., \& Šedová, K. (Eds.). (2007). Kvalitativni výzkum v pedagogických védách. Praha: Portál.

Torrance, H., \& Pryor, J. (2001). Developing formative assessment in the classroom: Using action research to explore and modify theory. British Educational Research Journal, 27(5), 615-631.

Vališová, A., \& Kasíková, H. (2011). Pedagogika pro učitele. Praha: Grada.

van der Velde, J. (1992). Technology in basic education. In T. Kananoja (Ed.), Technology Education Conference (s. 151-170). Helsinki: The National Board of Education.

Walberg, H. J. (1999). Productive teaching. In H. C. Waxman \& H. J. Walberg (Eds.), New directions for teaching practice and research (s. 75-104). Berkeley: McCutchen.

Wiggins, G. (1993). Assessment: Authenticity, context, and validity. Phi Delta Kappan, 75(3), 200-213. Yin, R. K. (2009). Case study research: design and methods. Los Angeles: Sage Publications.

Zimmerman, B. J., \& Dibenedetto, M. K. (2008). Mastery learning and assessment: Implications for students and teachers in an era of high-stakes testing. Psychology in the Schools, 45(3), 206-216.

PhDr. Jana Stará, Ph.D.

Univerzita Karlova, Pedagogická fakulta, Katedra preprimárni a primárni pedagogiky

e-mail: jana.stara@pedf.cuni.cz

PhDr. Karel Starý, Ph.D.

Univerzita Karlova, Pedagogická fakulta, Ústav výzkumu a rozvoje vzdèláváni

e-mail: karel.stary@pedf.cuni.cz 


\section{STARÁ, J., STARÝ, K. Teaching Goals in Primary Education or There and Back Again}

Aim: To describe how teachers of the junior classes in Basic School (ZŠ) think about teaching goals, which teaching goals they set themselves, how they communicate them to pupils and how they work with them in actual teaching.

Methods: A multi-case exploratory study, the cases each being a teacher's work with educational goals. The participants in the study were 10 teachers of the junior classes in Basic School. The methods employed were observation of teaching, in-depth semi-structured individual interviews with teachers, and content analysis of teaching artefacts.

Results: Educational goals do not appear in teaching in explicit form. During observation, implicit goals emerge - at the beginning of lessons when the programme is communicated, in the course of lessons in the tackling of learning tasks and above all in assessment processes including concluding reflections. The educational goals become most evident when criterial assessment is used. The quality and modes of work with goals were very various among the teachers in the study. In many lessons the educational goals, teaching methods, and assessment of pupils were at odds. In interviews the teachers did not explicitly mention the development of values as a goal in teaching.

Conclusions: When goals, content and assessment techniques are in harmony, this has benefits for pupil learning. Our analysis of statements by teachers and the responses of pupils has led us to the view that improving work with teaching goals has the potential to bring pupils greater gains from learning and to increase the quality of their education overall. In view of the big differences between teachers it seems to us important to individualise support offered to them.

Keywords: teaching goal, educational goal, primary education, implemented curriculum, case study, education in the social sciences and humanities. 